\title{
Hate, Lies, and Violence: The Dark Side of Pre-Modern Literature Why Would We Care? And Yet, the Key Rests in the Past to Solve Our Issues Today. With a Focus on the Stricker (Thirteenth Century)
}

\author{
Albrecht Classen \\ Department of German Studies, University of Arizona, Tucson, AZ 85721, USA.
}

\begin{abstract}
How to cite this paper: Albrecht Classen. (2021) Hate, Lies, and Violence: The Dark Side of Pre-Modern Literature Why Would We Care? And Yet, the Key Rests in the Past to Solve Our Issues Today. With a Focus on the Stricker (Thirteenth Century). Journal of Humanities, Arts and Social Science, 5(2), 281-294.

DOI: $10.26855 /$ jhass.2021.07.013
\end{abstract}

Received: November 11, 2021

Accepted: December 8, 2021

Published: December 31, 2021

*Corresponding author: Albrecht Classen, Department of German Studies, University of Arizona, Tucson, AZ 85721, USA.

Email: aclassen@arizona.edu

\begin{abstract}
Oddly, the more we turn to the past world in its literary manifestations, the more we recognize fundamental and universal aspects commonly shared across the globe by all people until today. There are virtues and vices, especially the Seven Deadly Sins. We have to observe, hermeneutically speaking, the tenuous passage through Scylla and Charybdis of idealizing and maligning the past, whereas the phenomena of hatred, envy, jealousy, dissimulation, the tendency to turn to violence, and to employ lies can certainly be observed in medieval literature as well, parallel to the glory of King Arthur's court or the world of the Grail. Whenever basic human attitudes or approaches are concerned, we discover both evilness and goodness, always in changing relationship to each other. This paper examines these issues by way of studying of a variety of medieval voices, of a major theological treatise on the Seven Deadly Sins, and of the didactic narratives by the Middle High German poet The Stricker.
\end{abstract}

\section{Keywords}

Seven Deadly Sins, hatred, lies, deception, disloyalty, betrayal, Marie de France, Ulrich Bonerius, Heinrich Kaufringer, The Stricker

\section{Introduction}

As a medievalist, I cannot help but marvel at the incredible disconnect between modern popular assumptions and false claims about the Middle Ages and, by contrast, the historical reality as scholarship has unearthed it over hundreds of years by now. It might amount to a cognitive dissonance among those who regard themselves and their societies in shining light, as the beacons of ideals and values, as the carriers of hope and confidence in the achievable of the near unachievable, and who contempt the past as a barbaric, primitive, subjugated, and violent world with little laws, even less ethical ideals and morals, and no care for the own neighbors. It is one of those common misconceptions every new generation suffers from, idealizing itself and rejecting the previous one as not as much developed as the present one claims to be-here disregarding the current trend toward pessimism regarding the future of our planet earth in environmental terms. In most cases, however, there is a huge misunderstanding at work, confusing scientific, technological, or medical developments, for instance, with morality, ethics, and simple humanity as the true benchmarks of the degree of civilization any society might pride itself of (Jones, Kostick, and Oschema, 
ed., 2020).

\section{Transdisciplinary Approaches to the Study of the Past}

Of course, it would be far from me to suggest any kind glorification of the Middle Ages as a shining world in strong contrast to the moral and ethical decline of the post-modern world, an equally erroneous and fundamentally flawed concept. This would then be the same mistake, only in reverse order. Instead, despite the many differences between the medieval past and us today, the conditions of humanity in ethical or moral terms have not changed much, unfortunately, and love and hatred continue to represent the extremes of the emotional household of most individuals (for hate today and how to combat it, see Murray, 2021). If we accept, to some extent, global universalities, then medieval literary texts can become very useful models for the psychological, criminological, ethical, and moral analysis of human behavior in the past, which in turn promises to shed valuable light on us today as the avatars of that previous generation (Rosenwein, 1998). As modern medievalist scholars have already observed for a long time, medieval literature has exerted a deep and extensive impact on modern writing, the arts, and culture at large (Nelson-Campbell \& Cholakian, ed., 2017). This study, however, does not intend to follow the path of reception history; instead, the focus will be a critical examination of the dark sides of the human nature as reflected already in medieval literary texts.

The history of emotions, for instance, demonstrates that most features of our household of passions were already fully in place among medieval people (Barclay, 2020; Broomhall \& Lynch, ed., 2020; for the historical dimension, see Rosenwein \& Cristiani, 2018). Those emotions can be grouped in a fairly simple set of categories, such as happiness, hatred, fear, insecurity, religious aspirations, greed, or curiosity. While research has focused much on the topic of love in the Middle Ages, here the purpose is to explore what we might learn about hatred, lies, and deception as themes in literary works as some of the strongest and most destructive human emotions (Sternberg \& Sternberg, 2008).

Hatred is often expressed particularly in literary texts, which thus become highly valuable media or documents for the critical discussion of this dangerous emotion with so many disastrous consequences for everyone involved. As unpleasant and revolting the fictional treatment of lies or treason, in short, of hatred might be, those easily prove to be highly valuable case studies for psychologists, counselors, neuroscientists, anthropologists, and this in close transdisciplinary cooperation with the literary scholars (for the concept of transdisciplinarity, see Orefice, 2020; Classen, 2021; Collett, 2021). As Basili and Sacco now state, "Building upon the wealth and depth of insight coming from literary studies, critical theory, and humanities and post-humanities research, a wide range of socio-psychological and neuroscientific disciplines is increasingly focusing upon fiction as a key source of social cognition (Basili \& Sacco, 2021). Of course, we must not ignore that both in the past and present, the events presented in fictional texts constitute at first a parallel world which does not overlap with the factual one (Addis \& Morris, 2010; for contrastive views, see Zunshine, 2006; Vermeule, 2010).

But for most people, at least for those who go just a little beyond the simple pleasure of reading as a banal form of entertainment without any degree of self-reflection, a narrative (fictional or not), an epic poem, a courtly love poem, or a fable-here also including modern online media, graphic novels, movies, etc.—constitutes a window through which they can gaze into specific human situations and conditions and begin to explore the issues at stake there (Kydd \& Castano, 2013; Oatley, 2016; Armstrong, 2020). Medieval literature can emerge in this process as a powerful toolkit to examine not only the history of people's emotions and attitudes, but also as a mirror of human culture, ethics, morality, laws, and political and economic structures (Johnson, 2012; Dresvina \& Blud, ed., 2020; Fudge, forthcoming).

Without going further into details here, recent neuroscientific investigations have confirmed the extent to which fictional texts could constitute simulation frameworks for the enactment and development of human emotions and reactions (Gallese \& Guerra, 2019). Literature and the arts have been around since time immemorial not simply by accident or for plain entertainment during one's free time. Instead, they have always served profound purposes, whether religion, ethics, morality, philosophy, history, or law (Boyd, 2018). As we can claim, literature or the arts are hence an expression of the human mind and provide insights into the workings of our brains, or our hearts, that is, of our souls (Armstrong, 2014). With regard to romantic love, for instance, a theme covered throughout the ages both in classical antiquity and the Middle Ages since ca. the twelfth century, modern science might help us to understand the great significance of the literary works. As Basili and Sacco conclude, fiction, or poetry, can "ultimately [be useful] for our capacity to probe not only the cognitive and emotional complexity of the processes of 
couple formation, but also of their metaphorical insightfulness into key aspects of the human experience of the world, in whose flux of change we are inevitably, and often unknowingly, immersed (Basili \& Sacco, 2021; in their conclusion, online; see also Stiles, Finger, \& Boller, 2013).

\section{The Phenomenon of Hatred}

Of course, hate as such would have to be broken down into some of its critical features or elements, that is, its conditions and causes, such as insecurity, lack of identity, envy and jealousy, and the strong need to establish one's own identity by means of rejecting all others (Scott \& Kosso, ed., 2002). Antisemitism, misogyny, racism, and other isms can all also be traced back to fundamental psychological problems of an individual or a collective kind. The sense of insecurity, of envy, and of inferiority thus proves to be critical in the formation of hatred, as we find out as being reflected countless times in literary texts. As Julia Kristeva suggests, "psychoanalysis is the key to serenity, with its processes of turning back, looking back, investigating the self, and refashioning psychical damage into something useful and beautiful. Constant questioning... is essential to achieving the coming to terms we all seek at the core of forgiveness" (Kristeva, 2010; book cover).

And yet, people throughout time have resorted to lies, to malignment, evil rumors, malicious acts, and have regularly allowed their hatred to come through in their ordinary lives. We cannot really judge whether there are more acts of violence as a result of this terrible emotion today than in the past. We know, however, that the continued presence of hatred requires from us in an ongoing process to come to terms with it, to isolate it, to analyze it, to reflect on its potential consequences, and to try to overcome it in order to help human society to survive, to grow, and to develop its own better character. Hatred is simply deconstructive! Studying literature with this focus in mind proves to be highly productive, as outlined above, especially if we turn to the Middle Ages when the narrative framework at first seems to project a certain degree of difference to us today which allows us to examine the issue through a hermeneutic mirror (globally, Brol, 2006; cf. also the contributions to Kappelhoff, Bakels, Lehmann, \& Schmitt, ed., 2019; Brokoff \& Walter-Jochum, ed., 2019). In essence, as our analysis will demonstrate in a quite surprising manner, medieval poets already demonstrated a fundamental awareness of the meaning of hatred and the impact of lies in all of human life.

\section{Global Observations in Literary Terms}

Already Middle High German poets eagerly engaged with questions concerning treason and deception, lies and revenge, such as in Herzog Ernst (ca. 1180/1220), the Rolandslied (ca. 1180), or the Nibelungenlied (ca. 1200). In fact, much of medieval and early modern literature is influenced by the concern with lies, breaking oaths of loyalty, and the undermining of trust as a result of hatred (Tracy, ed., 2019). The devastating outcome of the Nibelungenlied illustrates this most dramatically because the entire epic is deeply determined by the horrible consequences of lies, insecurity, fear, envy, and thus hatred. When the Netherlandish hero Siegfried appears at the court of the Burgundian kings, he triggers a wave of fear, hatred, and deep insecurity. This troubles the court steward Hagen the most, an ominous figure throughout, and he will be on the watch-out throughout the entire first part to keep this nemesis protagonist at bay, until he finally finds an excuse and an opportunity to eliminate him through murder (Schulze, ed., 2010; cf. Müller, 1998; Gephart, 2005).

Negative energy, however, almost always triggers a counter-development, and Siegfried's widow Kriemhilt then invests all of her resources and her entire life to the exacting of revenge, a process in which she has to accept as a price for the success of her plan the death of her entire family of Burgundians, of her second son (with King Etzel), and of the entire court of knights at the Hunnish court. A very similar process could have taken place in the medieval Spanish epic poem, El poema de mío Cid (ca. 1000) where the protagonist struggles hard as an exile to regain military and political status, but he never turns that energy against the king. However, when he is badly abused and painfully harmed by his sons-in-law, the Carrións, who had tried to murder their wives to compensate for their humiliation at El Cid's court, the protagonist restrains himself even further and seeks justice from the king, and can thus triumph at the end over his adversaries and regain fully his previous honor and even more (Rafel, ed. and trans., 2009). In most other heroic epics, however, the employment of lies, treason, and the display of hatred has catastrophic consequences and is also explicitly condemned, such as in the Old French Chanson de Roland (e.g., Genelon, ca. 1150) and in the Icelandic saga, Njál's Saga (ca. 1300).

The situation in the late Middle Ages was obviously not much better, as the critical analysis of the works by Elisabeth von Nassau-Saarbrücken and other fifteenth-century prose novels, such as the anonymous Malagis, indicate. 
Personal distrust, cheating, lying, deceiving, and ultimately treason on the highest political level emerge, unfortunately, as major themes in many different texts (Tracy, ed., 2019). Intriguingly, while some poets highlighted those issues within a private realm (marriage, friendship), others (Fortunatus, 1509) outlined how the personal strategies to commit treason could easily transpire into larger social conflicts, leading to the death of victims and perpetrators alike. We might want to go so far as to identify pre-modern literature as something like an "Ethikschmiede," certainly a neologism (a smithy for ethical ideals), but a very useful term to identify and characterize the public discourse of that time pertaining to evil emotions such as hatred or envy.

As Fidel Fajardo-Acosta has remarked, "the affections of the modern subject that cement its psychic economy were constructed during the Middle Ages as a romanticizing of the notions of love and freedom" (Fajardo-Acosta, 2010, 220). Unfortunately, hatred appears almost everywhere, whether in the form of persecution or accusations, deceptions and lies, whether as the result of fear or of ignorance, or of greed and selfishness. There would be hardly any medieval text without an individual expressing this deadly feeling and thereby emerge as the mortal enemy of the protagonist. The courtly protagonist or the heroic figure demonstrates ultimately his extraordinary qualities and abilities by way of resisting hateful individuals and fighting his/her way through the fundamental values of honor, dignity, goodness, and love.

Two impressive examples for this phenomenon prove to be Gottfried von Strassburg's Tristan (ca. 1210; Gottfried, 2020) and Wolfram von Eschenbach's Parzival (ca. 1205; Wolfram, 2006), and in both romances the problems are exacerbated through the use of lies, deception, cunning, dissimulation, and other strategies by background figures to defeat the main character/s (Classen, forthcoming). The situation looks very similar in contemporary European literature, whether we think of the lais by Marie de France (ca. 1190) or the Decameron by Boccaccio (ca. 1350), of the large corpus of fabliaux (twelfth through fourteenth centuries) or the tales by Geoffrey Chaucer in his Canterbury Tales (ca. 1400), with Dante Alighieri being the most dramatic and outspoken poet targeting the many different sins human beings can be culpable of. Undoubtedly, hence, once we turn a critical lens toward medieval literature, we quickly come across significant dimensions of negativity, that is, a host of lies, deception, dissimulation, and then hatred even if those strategies ultimately do not succeed in defeating the 'good' protagonist. Of course, all adventure stories with a glorious hero are predicated on the presence of evil characters who need to be overcome, so we are identifying here an archetypal element.

One of the best illustrations for this host of human problems can be discovered in the fables by the Bern Dominican poet Ulrich Bonerius, in his Edelstein (ca. 1350; The Gemstone; Bonerius, 2020), which would deserve particularly attention for that reason alone. Being a preacher and confessor, Bonerius was fully informed about human shortcomings, failures, and suffering. In his exactly one hundred narratives, some of which are completely of his own making and do not rely on the appearance of animals, as the genre would normally require, he mirrors the wide gamut of emotions, aggressions, hostility, mean-spiritedness, betrayal, disloyalty, lies, hatred, and so forth. We are confronted with topics such as ingratitude, violence, evil council, bribery, excessive fear, mockery, deception, fake beauty, malignment, lack of foresight, hypocrisy, arrogance, pride, envy, hatred, and raw violence (Stange, ed. and trans., 2016, 438-40).

Not surprisingly, countless clerical authors like Bonerius throughout the pre-modern age addressed the corpus of the so-called Seven Deadly Sins, which included anger/hatred and envy, pride and lust, with hatred probably being one of the most destructive forces in human life (Brogaard, 2020). As much as we tend to associate courtly literature with courtly ideals, the concept of love, knightly honor, honesty, dignity, and chivalry, such as displayed in Hartmann von Aue's Middle High German Erec (ca. 1170) or in the anonymous Middle English alliterative romance, Sir Gawain and the Green Knight (ca. 1370), as much do we have to be prepared to confront the dark side of human existence.

Another excellent example proves to be the verse narrative "Der verklagte Bauer" (The Accused Peasant) by the south-German poet Heinrich Kaufringer (ca. 1400), where a decent and upright peasant is falsely accused by the local priest of being a heretic or disbeliever who would deserve to be severely punished for his blasphemous statements (Kaufringer, 1972, no. 3; cf. my English trans., 2014/2019). The narrator characterizes him as an upright, honorable person (43), whereas the priest, the presumed authority figure, proves to be corrupt and hateful, greedy and envious. While the peasant pays all of his tithes as he is bound to, he owns much more and yet does not yield it to the priest who, driven by hatred and greed, thinks hard by himself how he could put shame and disgrace upon his opponent (56-59).

To strengthen his case, the priest then involves the local judge whom he alerts to the existence of this peasant 
who is not submissive enough and refuses to accept their authority (62). With the help of the judge, he hopes to break the honest man's resistance and independence: "und uns auch wesen undertaun” (72; he must be our subject). Since the judge equally eyes the peasant's wealth and would like to get his cut in this deal to destroy the innocent victim, he happily joins the priest's strategy to sue the unsuspecting man and thus to crush his opposition, to harm him in every possible way, and to rob him of his wealth (79-92).

Fortunately, the peasant is a smart man, very considerate, and knows how to strategize well in his life. He manages to appeal successfully to the bishop who then defends him, and can ultimately expose the priest as guilty of committing adultery with the judge's wife. Although he had been badly beaten already several times for this crime, the priest continued with this transgression, which the bishop finally punishes with a steep fine. The narrator then concludes: "Es ist gar ain guote tat, / das untrew iren herren hat / geslagen, das gefellt mir wol, / und das der unschuldig sol / davon komen unversert" (683-87; It is really a good thing that disloyalty strikes its own lord; I am pleased with that, and also that the innocent person gets away without any harm to himself). We could easily identify numerous other narratives in which Kaufringer targets the many evils in this world, whether cowardice (no. 6), deception and lying (nos. 9 and 11), murder (no. 14), wrath and abuse (no. 18), corruption (no. 20), cowardice (no. 23), evil advice (no. 31), or alcoholism (no. 32) (cf. Stede, 1993).

However, he also included narratives where the intelligent and honorable individual triumphs, such as in the story of the innocently accused peasant (no. 3), in the narrative of the mayor and the prince (no. 4), in the account of the pious miller's wife (no. 17), and of the devil and the student (no. 18). But the comments about human failures and transgressions dominate, and this simply because this poet, like many of his contemporaries, engaged with common issues in his ordinary social context; and to adapt the famous line by Shakespeare for our purposes, there was something rotten in the world of the Middle Ages, of course.

\section{Fasciculus morum-Critical Reflections on Wrath}

\section{A Theological Perspective}

To pursue this topic further and to draw from some of the theoretical reflections from that period, let us also examine what one of the many clerical authors had to say about the Seven Deadly Sins (Bloomfield, 1952; Newhauser \& Ridyard, ed., 2012; Clarke, 2018), comments which all prove to be of timeless relevance since that list could be easily used for any modern psychological and neuro-cognitive analysis of people's moral and ethical failures and shortcomings. The highly popular Fasciculus morum (shortly after 1300; Wenzel, ed., 1989), which must have exerted tremendous influence on late medieval mentality and spirituality, covers all of those sins and examines each one in great detail.

The anonymous author was not at all the first one to reflect on those Seven Deadly Sins, which had been put together as a canonical list already in late antiquity first by one of the Desert Fathers, Evagrius the Solitary (345-399) and then, most influentially, his pupil John Cassian (360-ca. 435) with his book The Institutes, a Latin translation of his master's text in Greek. Evagrius, however, had also used a number of older sources, especially Aristotle's Nichomachian Ethics, the most important philosophical treatise from antiquity which was deeply impactful throughout the entire Middle Ages and far beyond. We must also not forget the truly influential Hebrew Book of Sirach, also called the Wisdom of Sirach or Book of Ecclesiasticus by Ben Sira of Jerusalem from ca. 200-175 B.C.E, which was later translated into Greek by an anonymous scholar in Egypt (https://en.wikipedia.org/wiki/Sirach).

The Seven Deadly Sins gained their final form and narrative when Pope Gregory I published his Commentary on Job, that is, his Books of the Morals, III, 6, Book XXXI, in 590 C.E. (http://www.lectionarycentral.com /gregorymoralia/book31.html). Virtually all medieval theologians and philosophers, such as famous Thomas Aquinas, referred to it, expanded on it, and explored the practical applications of the teachings contained in that list (for a dense summary, see Hödl, 1997). Little wonder that preachers throughout Christian Europe referred to those Seven Deadly Sins and expounded on them regularly in their sermons both in the Middle Ages and far beyond.

Virtually all of those sins could be incorporated into our subsequent discussion, but wrath, or hatred (ira), seems to be a good umbrella term for all those behaviors characterizing the dark side of medieval society, that is, of people in that time period, as mirrored also in the various literary manifestations. In the Fasciculus morum, we receive a full description of the features of wrath, some of the details of which will be of relevance for us, particularly because the author offers such a detailed scholarly discussion of its origin, different features, and ethical and moral evaluation. "wrath which is," according to Augustine, "the unbridled desire always to get vengeance and never to have pity”" (117). 
Wrath, hence all of its ramification, including lies and deception, destroys the soul and obstructs God's grace, moving the person suffering from it to a member of the devilish community (119). Confession and penance would, however, help to overcome wrath and promise to heal the affected person. The author identifies, in particular, hate and revenge as the strongest expressions of wrath, or hatred. Most interestingly, as the narrator emphasizes, as if he were speaking in the twenty-first century, "many people today cannot take their revenge with material weapons and therefore retain hatred through hardened anger in their hearts" (119-21). One should reject evil in any shape and form, but should not hate the person as God's creation.

One of the worst consequences of wrath would be "when anger and hatred come upon the house of our soul, they overthrow its four affects, that is, the four virtues, and destroy whatever good comes to life in it" (121). Many people are in no power to release their wrath and let it simmer for a long time until an opportunity arises to exact their revenge. "Such people are commonly confounded in their own wrath, as is shown typologically in Exodus 28 by Pharaoh, who unjustly persecuted the children of Israel and drowned with his army in the Red Sea" (121-23). God, however, would always show mercy even in the worst case of wrathful behavior as long as the individual would show repentance.

Specifically, the preacher identifies the hypocrites, the prideful ones, and lechers (125). The only solution for those sinners guilty of wrath and its side-effects would be "to reflect carefully on the three parts of prudence: first on the past, remembering what evil you have done, what good you have left undone, and how few good things you have accomplished" (127). One should not be overconfident in God's mercy, but one should also not despair about not receiving it under the right conditions (127). But as much as the author subscribes to the value of patience as a tool to combat wrath, this does not fully address the intricacies of these evil emotions in human life. Instead, he continues, of course, and also examines envy, which he defines as "sadness about someone else's happiness and glee about someone else's ruin and adversity” (149), which is called both in modern German and in English "Schadenfreude".

The envious person "will gladly speak well of his neighbor but with an evil intention" (151), and when he knows something bad about the other, he will aggressively spread rumor to harm the poor victim even further. Finally, the one filled with envy will at first praise the lucky person, but then would turn around and try to destroy his/her public reputation, having been originally recognized as a 'friend' (151). The author also offers a concrete example of how a rich person might use all of his/her legal and political might to rob a poor person of his last remaining piece of land for selfish reasons (153). All this leads the author to identify envy as "the most evil daughter of the devil" (155) because the culprit "strives to gnaw off and diminish as much as he can the good that he sees in his neighbor" (157).

All this then leads over to the discussion of grumbling and backbiting (159-65), lying (165-69), and flattery (169-73). The final definition, according to Pope Gregory I, then reads: “Envy is a tree, whose root is pride, its trunk ill-will, its branches rancor and hatred, its leave flattery, backbiting and lies, its blossoms pallor and emaciation, and its fruit grief and joy"” (173). Truly evil people subscribe to flattery and pretend to mean the best for the respective others, but in reality, flatterers are nothing but whores who "speak ill from behind, lie, laugh, and deride" (173).

Without going further into detail, suffices to summarize the author's conclusion about the dangers in this world for the soul. He defines "carne et mundo" (722; flesh and the world) as the most dangerous threats to one's well-being, all emanations from the devil. Of course, the author was a member of the Church, and harbored a rather negative sentiment about this life as determined by sinfulness and the workings of Satan. Nevertheless, we are confronted here, as in many other contexts, with a highly detailed and concrete discussion of the dark side of medieval society and mentality. Of course, we do not have to accept that discussion as the ultimate statement concerning the pre-modern world, but the Fasciculus morum serves as an excellent reminder about the countless problems which existed already at that time.

\section{The Stricker-A Middle High German Poet Speaks Up}

Most medieval didactic authors had negative comments to share about their society at large and about people in specific. Some of Walther von der Vogelweide's song stanzas (ca. 1195-ca. 1220) are simply brutal reminders of the downfall of the courtly ideals, against which even the best poets could not rally enough optimism and idealism in their romances or poems (Goldin, ed. and trans., 2003; Müller, 2009). His contemporary poet, Marie de France, expressed rather explicit comments about the ills of her society, charging the rich and powerful, above all, for their 
corruption, abuse, and many types of sinful behavior (Spiegel, ed. and trans., 1994). And only ca. hundred years later, the famous Dante Alighieri penned his timeless and globally famous Divina commedia (completed in ca. 1320), blasting away all remaining illusions about the good nature of human beings.

Of course, all those didactic poets were not simply driven by complete pessimism and hopelessness, as C. Stephen Jaeger has tried to argue, perhaps too excessively, in his analysis of a number of contemporary works (Jaeger, 2003). The motivation to publish their texts was driven, of course, by the hope for improvement, for reaching out to good people, and for the possibility of improvement of society at large, as is the case with all didactic literature (Ruys, ed. 2008). Nevertheless, these examples and those that I will discuss below, easily shatter any illusions we might have had about the ideal conditions in the pre-modern world. The truth about people in the past lies, of course, somewhere in the middle, and yet we have to acknowledge the severe warnings by some poets or simply their reflections of human behavior as mirrors of the dark sides both of the courtly world and of the Church, of the urban world and of the peasantry.

The Stricker, who sheds more light on these conditions through his numerous didactic verse narratives, is famous for his wide range of literary genres. Flourishing between ca. 1220 and 1240, he composed a new version of the Rolandslied by the Priest Conrad, in his Karl der Große. He also created an innovative type of courtly romance in his Daniel von dem Blühenden Tal, and wrote a number of fables. Most significantly, The Stricker also invented the literary figure of the roguish Priest Amîs, who was later to find its avatar in the highly popular Till Eulenspiegel (ca. 1500/1510; Classen, “The Stricker,” 2021). Amîs operates most successfully in a rather evil world and invites us to laugh with him over foolish and hateful people.

As much as The Stricker's verse narratives (mæeren) invite the audience to enjoy the account as a form of entertainment, we can easily realize the extent to which we suddenly face a wide range of literary reflections of hatred, lying, deception, dissimulation, envy, and aggression (González and Millet, ed., 2006). The poet deals primarily with marital conflicts, but also engages with political, social, and material conflicts (Ehrismann, ed. 1992). Significantly, wherever we turn in The Stricker's texts, we discover huge tensions between people either as the result of miscommunication or because of envy, jealousy, or ignorance and stupidity. As much as the poet endeavored to entertain his audience with seemingly light literary accounts, as much do his mceren reflect on often rather painful experiences in people's private lives.

There are too many examples among The Stricker's work to engage with all of them in greater detail here. The present purpose, after all, cannot be to offer comprehensive interpretations; instead, the focus of the following analysis rests on identifying noteworthy cases of hatred, lying, deception, or dissimulation, all of them as mirrors of the dark side of medieval society. The poet does not limit himself to any specific social class, and discusses rather conflicts and tensions between peasants, kings, burghers, and others and makes the obvious effort to identify situations in which all kinds of people reveal their character weakness and sinfulness.

In "Der kluge Knecht" (no. 15), we hear of an ordinary farm where the peasant's wife has an affair with the priest, which was a rather common topos in late medieval literature (Beine, 1999, 123, 127, et passim). The farmhand, who is identified immediately as intelligent and smart, realizes what is happening in secret, but he knows that he cannot reveal it directly to his master without having concrete evidence in his hands. In fact, he would risk the peasant's anger: "er würde im gehaz" (9; he would begin to hate him). The wife makes every effort to send the two men off to their work in the fields as early as possible, but the servant insists that he needs a good breakfast without which he could not handle the new day. This triggers extensive anger in the wife, who wants to get ready for her lover, but the farmhand uses this as part of his overarching strategy to expose the woman. Later, the young man returns to the farm, secretly observes what she has prepared for the meeting with the priest, and also notices where she hides the food and the priest when her husband suddenly returns home to the surprise of everyone.

Both men then sit down to eat their own simple food provided by the wife, who secretly curses them (204) but is helpless in that situation. The farmer also feels some anger over the renewed delay, but since he knows of the farmhand's great qualities as a worker, he suppresses his irritation. Then the farmhand begins to tell stories through which he can reveal the location of all that food and then expose the priest, which destroys the woman's efforts to have an affair with him. All this makes the husband deeply angry (280), but this wrath appears this time as fully justified in light of the wife's transgression. The priest is badly punished, being forced to pay a large amount of money, whereas the wife is severely beaten. From that day on, the husband no longer feels the same love for her (300-02) because she broke their mutual oaths of marital love and loyalty.

By contrast, the peasant strongly appreciates his smart farmhand who handled the situation rationally and intelligently, achieving his goal of revealing the truth to the farmer without having to face counterclaims and bitter argu- 
ments since the wife would have denied all charges, of course. As the narrator finally comments, due to her self-defense, the farmhand would then have become a victim of his master's hatred without any solid evidence in his hands. She would have simply stated that the farmhand hated her: "durch sînen boesen haz" (333; through his evil hatred). However, all that did not occur because the farmhand fully understands his own limitations in exposing the wife, so he resorted to a sophisticated narrative strategy and could thus help the peasant to learn the truth himself. We thus observe that the poet predicated the entire narrative on the motif of hatred which could easily erupt when people accuse each other of wrongdoing without having access to hard-core data or evidence. In other words, while the story is based on a rather traditional theme of adultery with a priest, on a deeper level the poet explored the question of legal evidence, the dangers of uncontrolled hatred, the consequences of dissimulation, and the power of lies in cases of charges concerning social, ethical, and moral wrongdoing.

In The Stricker's "Die eingemauerte Frau” (no. 12; The Enwalled Wife), the focus rests on a highly disagreeable wife who irritates her husband without end, constantly contradicting him at all costs. Whatever he tries to do to amend her behavior, she fights back, and even the worst beating does not achieve anything for the husband. From our point of view, of course, we recognize here a horrible case of domestic violence since he is hitting her with a stick so badly that she is bleeding profusely, with her skin being detached from her body. Yet, even then she defies him arrogantly, which forces him, the absolute patriarch, to resort to another strategy. He is so furious about his wife that he has a small room built within his house with only a little window in the wall, and then imprisons her there (see, e.g., Hofmeister, 1992; Volfing, 2010). She is fed very poorly and must witness how her husband enjoys life with dinners and mistresses at his side, which continues for so long until she finally breaks down and submits entirely, especially because she has no supporters among her own family members whom the husband had brought over to his side through favorable financial treatments.

In explicitly patriarchal language, the narrator then remarks that the Holy Ghost entered her body and chased away her "groziu übel" (119; great evilness). But he also reveals the psychological terror which her husband had exerted since she could not see any end to her torments at his hands and felt completely abandoned by everyone. There are no explanations regarding the reasons for her hateful outbursts against him, except the simple recalcitrance and obstructionism. At the same time, he is not willing to become victimized by her and resorts to extremely violent counter-measures. At the end, the husband wins the battle because she entirely submits under him both physically and mentally.

To a priest who listens to her confession she admits her full evilness and announces that it has now left her. As was so common in the Middle Ages, she blames her bad behavior on the devil and now wants to repent her sinfulness which led her to oppose both her husband and also God (157). She begs her husband to let go of his wrath (208) and to display his mercy toward her (214), which then also works out well because she becomes totally subservient to him and to God and commits herself as a tool for patriarchal government, pledging to drive out the evilness of every woman who might be a victim of this sinfulness (262-65). At the end of a seven-day feast, she pronounces explicitly that all her evil character had been really directed against God and that she would work from then on to convince all women to obey their husbands - the utter victory of male rule!

We are, of course, not told why these women are determined by this alleged evilness and how the female protagonist would teach themselves to pursue a different path as obedient wives. But the overall outcome is a stereotypical characterization of women as prone to aggression and hostility, globally expressed as husbands' sorrow and suffering in marriage. This verse narrative could hardly be more misogynist, indicating the strategies which men could use in the future to bring their wives to 'reason', and this by force and religious threats. Intriguingly, many men in the audience, referred to in the epilogue, agree that they would need a healing session for their wives since they have been badgered by them already for a long time. Physical violence and religious terror emerge here as the principle tools which husbands should resort to when they would need to fight back against their wives and their evilness.

Of course, there are no explanations for the women's words and actions, and no reasons why the men feel so repressed and subjugated. But the overall picture conveyed here is one of hatred and violence, of strife and battle within married life. The poet subscribed clearly to very traditional perspectives and urged his audience (male and female) to observe traditional, Church-approved role models according to the patriarchal system (for a rich anthology of textual examples, see Blamires, ed., 1992). As abhorrent as this story might be for us today, it sheds valuable light on the reality of married life at that time, often determined by conflicts because of contested gender roles.

Curiously, however, The Stricker also included a verse narrative determined by the very opposite perspective, 
"Das Ehescheidungsgespräch” (no. 18; The Discussion of Divorce), in which a husband, resorting to a cascading rhetorical approach, ultimately announces that he and his wife must separate immediately; he can no longer stand her because she represents the devil himself. For him, his wife is "boese unde arc" (39, bad and cunning), characterized by evilness and miserliness, looking shriveled and wasted: "mir grûset, swenne ich dich sehen soll” (44; I am horrified when I am forced to look at you). He would survive only if he could be free of her.

In response, however, the wife turns the entire argument around, counting backwards the time they would still stay together, first until the next morning, then for another week, two weeks, six weeks, etc. Ultimately, she insists that they will have to cohabitate until the end of their lives, and neither the devil nor God would be able to do anything about that. Moreover, if he dared to speak up against that, "ich zebriche dich rehte als ein huon, / sprichest einez wort dâ wider” (96-97; I will rip you apart just like a chicken if you speak up with one word against this).

The poor man is incapable to withstand that flood of announcements and threats and immediately cowers before her, blaming the alcohol that he had consumed for his own foolish words and begging for her forgiveness: "vrouwe, du solt den zorn lân, / wan ich bin trunken dîsen tac" (102-03; Lady, let your wrath go because I am drunk today). Ironically, he then sings a song of praise of her virtues and announces that she is his most beloved wife (110-11). The husband thus achieves his goal, she forgives him, they both let go off of their wrath (129), kiss each other, and join in peaceful married life: "dâ ergie ein suone under in, / diu grôze vröude mahte” (132-33; they both forgave each other which created great joy).

Since we are not given any background information to this story and cannot learn about the reasons for his anger, the narrative focus rests only on the rhetorical device pursued by the poet, with both marriage partners talking to each other in a reverse sequence, him trying to get rid of her, her ensuring that this won't happen. The husband's arguments are not developed at all; he simply seems to follow the trap of traditional misogyny and attempts to accelerate their divorce more and more. However, she simply counter acts his statements and turns them so completely around that he has no defense left, submits entirely under her and acknowledges her as his beloved wife he would never want to separate from. The poet grants him fifty verses to make his case, whereas she receives forty-seven verses. The rest of the text consists of their further conversation in which he begs for her forgiveness, and she grants him just that, which leads to the mutually agreeable outcome: "hie nam der zorn ein ende" (129; herewith the wrath was overcome).

Whereas before they had engaged in a battle of words against each other, now they lie down together in bed and enjoy their lovemaking, which results in their happy laughter (134), a most significant moment of transformation (Classen, ed, 2010). We might even assume that the poet was only playing with two literary traditions, misogyny and praise of women, depending on the context, and intended to bring them together in this intensive debate poem in which she completely gains the upper hand, although he does not seem to mind her victory because he loves her and can enjoy her in their physical lovemaking.

In "Der arme und der reiche König” (no. 20), the topic specifically rests on hatred which the rich king feels against the poor, although he has no rational reason to feel so. His councilors explicitly warn him against this irrational approach since the poor king has no guilt in whatever regard. Moreover, they warn him that already his father had to accept shameful defeat whenever he had tried to unleash his hatred against the opponent (p. 164). The young man knows too well how foolish he argues, but he still insists that the poor king had done so harm to him in his dream that he would now be justified in his effort to avenge this in concrete terms. His goal is to destroy the other: "der râche erwinde ich niemer, / unz ich im sîn êre benime” (30-31; I will never abstain from seeking revenge until I have robbed him of his honor). His advisors, whom the narrative identifies as "wîse" (39; wise), are greatly displeased with his handling of this matter and collectively disapprove of his attitude, but they are powerless to stop him.

Fortunately, the poor king soon finds out what the charge against him consists of, and in his smartness and intelligence he turns it all around and makes a fool of the young king, telling him to take as captives all those of his knights whose shadows he can see in the water; that is, only these shadows and not the real people. In short, he identifies the rich king's dream as what it is, a simple imagination, which would be equivalent to the shadows, and this then settles the case since the rich king has no power to enforce his real demands. He becomes the object of all of their laughter and ridicule, but the poet thus identifies hatred as the result of ignorance and foolishness, though it could have catastrophic consequences. In his epimythium, The Stricker then concludes that "man verliuset der unwægen spil / von den schulden harte vil, / daz si alle tumbe sinne hânt, / die daz unwægeste ane gânt” (181-84; you often lose the risk-driven game because those people have a dumb mind who tackle the imponderabilia/risk; cf. Classen, "Neid und Hass," forthcoming).

In "Der Richter und der Teufel” (no. 21), the topic focuses on a judge who is completely corrupt and involved in 
many crimes. Moreover, people everywhere hate him because of his vicious nature and his abusiveness, exploiting the authority of his office to such an extent that he suffers from extremely ill repute. Little wonder that one day the devil waits for him, and they both strike a deal that the devil should be allowed to take whatever people honestly wish him to have. Since it is a market day, many people have come together, and some of them utter curses, but the devil reminds the judge each time that they did not really mean what they said.

But then they encounter an old widow from whom the judge had forcefully taken her only cow, perhaps as a payment for an alleged crime. The widow bitterly laments this injustice and evil deed against God, and she also points out that she thus has lost her only source of nourishment and is now suffering from malnourishment, depending on begging. Consequently, she appeals to God, begging him that He would allow the devil to take the judge's body and soul (199-201). This proves to be the only fully trustworthy statement from the various people when they invoke the devil, which thus allows the latter to go into action and to grab the judge by his hair and abduct him in front of all people. Thus, the man's evilness receives its appropriate punishment, as the narrator emphasizes (215-24).

The Stricker also formulated numerous comments about people's misbehavior, sinfulness, and evilness in his fables, allegorical narratives, and in his Minnereden (accounts about proper behavior at court and in the presence of ladies). But I would like to conclude with a most intriguing story, "Der Riese" (no. 14), where we are not confronted with an example of hatred, but individual weakness, cowardice, foolishness, and brutality, another set of horrendous character weaknesses that correspond in many ways to the Seven Deadly Sins, though the situation here pertains more to social and ethical corruption.

A group of twelve men desperately tries to find a safe haven late at night, caught in a dark forest. They finally reach a house, where they are greeted by a woman. At that very moment, her husband, a cannibalistic giant, approaches, and she urges them to hide in the attic, otherwise the monster would kill them all. The giant, however, immediately smells their presence and demands that they hand over the weakest among them, otherwise they all would have to die. They comply, but he is not satisfied with this. Instead, he demands ever new victims until only one man is left, who tries to defend himself, but it is too late. As the giant tells him, and us, "'dô du selbe zwelfter wære, / dô soldestu dich hân gewert, / sô möhtest dich hân genert, / dîn wer ist nu dâ hin'” (62-65; when you were twelve, you should have defended yourself, and you would have succeeded; but now your defense is useless).

The narrator extrapolates from this that many princes act the same way, displaying great evilness when they want to expel an entire family from the country. They first attack the weakest family member, then go for the next one, until they are all gone. He who wants to protect himself ought to fight right away and should not wait until the stronger person comes after him. But individual weakness and character flaws easily rise to the surface and allow those filled with hatred, evilness, and aggression to succeed in their own efforts. There is, after all, throughout the world much sinfulness, there are countless failures in human terms, but if people cooperate and fight together, also against a prince's hatred, they might have a chance.

\section{Conclusion}

It might be worth to consider briefly one of The Stricker's fables, "Der Hase” (no. 11) to reach a conclusion of our discussion so far. In this tale, we hear that a rabbit would always return to its wild nature even if it had been kept on a leash for ten years. The interpretation implies that a person who has always observed his honor would become a wild and dishonorable individual once he would lose honor out of sight. The poet thus indicates that virtues and honor, as dignified as they might be, can get easily lost because they are culturally acquired and are not part of human nature, or of our genes, as we would say today. Hence, hatred, envy, lies, deception, or dissimulation always wait for their time, and people are always subject to failure in upholding their own ideals.

Little wonder that the representatives of the early Christian Church formulated so powerfully and persuasively the concept of the Seven Deadly Sins. Unfortunately, those are all still with us, and they seem to be part of the human spiritual and mental architecture. Hence, it makes perfect sense to focus on literary examples, such as the mæren by The Stricker, in which we come across numerous examples of hatred, envy, deception, dissimulation, but then also lust, sloth, and greed. We might hence wonder whether we as people are ever capable of changing our ways, or whether we will have to deal with those vices as part of our genome, again using a modern term. As all didactic poets, especially those composing fables, have indicated throughout time, the need to educate people will never go away. Unfortunately, those sins or vices need to be addressed by every new generation, even though the external circumstances, the material conditions, are changing all the time. 
This then allows us to conclude that issues such as hatred, envy, pride, or greed are part and parcel of virtually all of human culture. The medieval examples discussed here reveal the extent to which human shortcomings are simply there to be engaged with over and over again. But why then literary examples? Why could we not limit ourselves to medical, theological, maybe psychological, and philosophical studies of those phenomena? We have realized that we could take a rather dim view of the Middle Ages, if we select dark glasses, that is, examine them in negative terms, and this in notable contrast to the shining images produced in courtly romances and poetry dedicated to chivalry and love. But not everything was catastrophic, destructive, hateful, or vicious. Just as today, we as people have to make our way through difficult times and challenging conditions, and some make it and reach their goals, others do not and fall back to their vices.

In order to understand all those phenomena, the literary examples prove to be most engaging and insightful, providing metaphors, images, or illustrations of those processes determining our psychological household. Studying the works by Marie de France, Ulrich Bonerius, Dante Alighieri, Heinrich Kaufringer, and, above all, The Stricker, as I have endeavored here, makes it possible to plunge into concrete life conditions as outlined in fictional terms, and there we can then observe what is really going on under specific circumstances, and what consequences might arise from them. Ultimately, as the cases selected here have demonstrated, the study of lies, deception, dissimulation, and hatred can begin exceedingly well with the help of medieval literature. Those texts indicate clearly that the courtly world was not at all any better than our own world, and that medieval society was not necessarily worse in ethical and moral terms than our own. What we can thus conclude is that the study of hatred finds most useful illustrative material already in medieval didactic narratives. Transdisciplinary research, combining modern cognitive sciences, neuro-science, psychology, history, art history, and literary history, thus promises to yield deep insights into the mental architecture of the human mind, both then and today.

\section{References}

Addis, Michela and Morris B. Holbrook. (2010). "Consumers' Identification and Beyond: Attraction, Reverence, and Escapism in the Evaluation of Films.” Psychology \& Marketing, 27: 821-845. https://doi.org/10.1002/mar.20359.

Armstrong, Paul B. (2014). How Literature Plays with the Brain. The Neuroscience of Reading and Art. Baltimore: Johns Hopkins University Press.

Armstrong, Paul B. (2020). Stories and the Brain: The Neuroscience of Narrative. Baltimore: Johns Hopkins University Press.

Barclay, Katie. (2020). The History of Emotions: A Student Guide to Methods and Sources. London: Bloomsbury.

Basili, Lorenza Lucchi and Pier Luigi Sacco. (2021). "Fictional Narratives as a Laboratory for the Social Cognition of Behavioral Change: My Ajussi." Humanities Open Access, online at https://www.mdpi.com/20760787/10/4/120/htm.

Beine, Birgit. (1999). Der Wolf in der Kutte: Geistliche in den Mären des deutschen Mittelalters [The Wolf in the Priest's Vestment: Clerics in the Verse Narratives from the German Middle Ages]. Braunschweiger Beiträge zur deutschen Sprache und Literatur, 2. Bielefeld: Verlag für Regionalgeschichte.

Blamires, Alcuin, ed., with Karen Pratt and C. W. Marx. (1992). Woman Defamed and Woman Defended: An Anthology of Medieval Texts. Oxford: Clarendon Press.

Bloomfield, Morton W. (1952). The Seven Deadly Sins: An Introduction to the History of a Religious Concept, with Special Reference to Medieval English Literature. Studies in Language and Literature. East Lansing, MI: Michigan State College Press.

Bonerius, Ulrich. (2020). Albrecht Classen, trans. The Fables of Ulrich Bonerius (ca. 1350): Masterwork of Late Medieval Didactic Literature. Newcastle upon Tyne: Cambridge Scholars Publishing.

Boyd, Brian. (2018). “The Evolution of Stories: From Mimesis to Language, from Fact to Fiction.”WIREs Cognitive Science 9: e1444. 1517; https://doi.org/10.1002/wcs.1444.

Brogaard, Berit. Hatred: Understanding Our Most Dangerous Emotion. Oxford Scholarship Online. New York: Oxford University Press.

Brokoff, Jürgen and Robert Walter-Jochum, ed. (2019). Hass/Literatur: literatur- und kulturwissenschaftliche Beiträge zu einer Theorie- und Diskursgeschichte [Hatred/Literature: Literary and Cultural-Historical Contributios]. Lettre. Bielefeld: transcript.

Brol, Nadia. (2006). Neid und Hass: woher sie kommen und was sie bewirken; eine soziologische Analyse [Envy and 
Hatred: Their Origin and What They Effect: A Sociological Analysis]. Saarbrücken: VDM Verl. Müller.

Broomhall, Susan and Andrew Lynch, ed. (2020). The Routledge History of Emotions in Europe 1100-1700. London: Routledge.

Clarke, Kevin M., ed. (2018). The Seven Deadly Sins. Sayings of the Fathers of the Church. Washington, DC: Catholic University of America Press.

Classen, Albrecht, ed. (2010). Laughter in the Middle Ages and Early Modern Times: Epistemology of a Fundamental Human Behavior, Its Meaning, and Consequences, ed. Albrecht Classen. Fundamentals of Medieval and Early Modern Culture, 5. Berlin and New York: Walter de Gruyter.

Classen, Albrecht. (2021). “The Stricker,” The Literary Encyclopedia, first published 16 August 2021, online at: https://www.litencyc.com/php/speople.php?rec=true\&UID=14777.

Classen, Albrecht. (2021). "Transdisciplinarity_A Bold Way into the Academic Future, from a Medievalist Perspective, or the Rediscovery of Philology?”, Humanities Open Access 10: 96, Aug.; online at: https://www.mdpi.com /2076-0787/10/3/96.

Classen, Albrecht. Forthcoming. "Neid und Hass auf den anderen: Universale Probleme in höfischen Romanen und Verserzählungen des deutschen Mittelalters. Gottfried von Strassburg, Wolfram von Eschenbach, Der Stricker und Heinrich Kaufringer" [Envy and Hatred of the Other: Universal Problems in Courtly Romances and Verse Narratives from the German Middle Ages: Gottfried von Strassburg, Wolfram von Eschenbach, Der Stricker und Heinrich Kaufringer], to appear in Menschen als Hassobjekte: Interdisziplinäre Verhandlungen eines destruktiven Phänomens [People as Objects of Hatred: Interdisciplinary Investigations of a Destructive Phenomenon], ed. Arletta Szmorhun and Paweł Zimniak. Göttingen: Vandenhoeck \& Ruprecht.

Collett, Guillaume. (2021). Deleuze, Guattari, and the Problem of Transdisciplinarity. London: Bloomsbury Publishing PLC.

Dresvina, Juliana/Blud, Victoria, ed. (2020). Cognitive Sciences and Medieval Studies: An Introduction. Religion and Culture in the Middle Ages. Cardiff: University of Wales Press.

Ehrismann, Otfrid, ed. (1992). Der Stricker. Erzählungen, Fabeln, Reden. Mittelhochdeutsch / Neuhochdeutsch. Stuttgart: Philipp Reclam jun.

Fajardo-Acosta, Fidel. (2010). Courtly Seductions, Modern Sujections: Troubadour Literature and the Medieval Construction of the Modern World. Medieval and Renaissance Texts and Studies, 376. Tempe, AZ: Arizona Center for Medieval and Renaissance Studies.

Fudge, Thomas A. Forthcoming. "Laughing, Crying and Killing: Emotions at Stake in Medieval Bohemia.” Mediaevistik 34.

Gallese, Vittorio and Guerra, Michele. (2019). The Empathic Screen. Cinema and Neuroscience. Oxford: Oxford University Press.

Gephart, Irmgard. (2005). Der Zorn der Nibelungen: Rivalität und Rache im "Nibelungenlied" [The Nibelungens" Wrath: Rivalry and Revenge in the "Nibelungenlied"]. Cologne, Weimar, and Vienna: Böhlau Verlag.

Goldin, Frederick, ed. and trans. (2003). Walter von der Vogelweide. The Single-Stanza Lyrics. New York and London: Routledge.

González, Emilio and Victor Millet, ed. (2006). Die Kleinepik des Strickers: Texte, Gattungstraditionen und Interpretationsprobleme [The Short Verse Narratives by The Stricker: Texts, the History of Genres, and Problems of Interpretation]. Philologische Studien und Quellen, 199. Berlin: Erich Schmidt.

Gottfried von Strassburg. (2020). Tristan and Isolde. Ed. and trans., with an intro. by William T. Whobrey. Indianapolis, IN, and Cambridge: Hackett.

Hödl, L. (1997). “Todsünde.” [Deadly Sin]. Lexikon des Mittelalters. Vol. VIII. Munich: Lexma Verlag, 839-40.

Hofmeister, Wernfried. (1992). "Rebellion und Integration in Strickers 'Eingemauerter Frau’.” [Rebellion and Integration in Stricker's "Eingemauerte Frau”]. Mediaevistik, 5: 71-77.

Jaeger, C. Stephen. (2003). “Pessimism in the Twelfth-Century 'Renaissance'.” Speculum, 78(4): 1151-83.

Johnson, Dan R. (2012). “Transportation into a Story Increases Empathy, Prosocial Behavior, and Perceptual Bias To- 
ward Fearful Expressions.” Personality and Individual Differences 52: 150-155. https://doi.org/10.1016 /j.paid.2011.10.005.

Jones, Chris, Conor Kostick, and Klaus Oschema, ed. (2020). Making the Medieval Relevant: How Medieval Studies Contribute to Improving Our Understanding of the Present. Das Mittelalter: Perspektiven mediävistischer Forschung, 6. Berlin and Boston: Walter de Gruyter.

Kappelhoff, Herrmann, Jan-Hendrik Bakels, Hauke Lehmann, and Christina Schmitt, ed. (2019). Emotionen: ein interdisziplinäres Handbuch [Emotions: An Interdisciplinary Handbook]. Berlin and Heidelberg: J.B. Metzler Verlag.

Kaufringer, Heinrich. (1972). Werke, ed. Paul Sappler. Tübingen: Max Niemeyer.

Kaufringer, Heinrich. (2014/2019). Love, Life, and Lust in Heinrich Kaufringer's Verse Narratives. 2nd rev. ed. Medieval and Renaissance Texts and Studies, 467. MRTS Texts for Teaching, 9. Tempe, AZ: Arizona Center for Medieval and Renaissance Studies.

Kristeva, Julia. (2010). Hatred and Forgiveness. European Perspectives. New York: Columbia University Press.

Kydd, David C. and Emanuele Castano. (2013). "Reading Literary Fiction Improves Theory of Mind.” Science, 342: 377-380. https://doi.org/10.1126/science.1239918.

Müller, Jan-Dirk. Spielregeln für den Untergang: Die Welt des Nibelungenliedes [Rules of Game for the Catastrophe: The World of the Nibelungenlied]. Tübingen: Max Niemeyer.

Müller, Ulrich. (2009). “Walthers Sangspruchdichtung.” [Walther’s Didactic Stanzas]. Brunner, Horst, Gerhard Hahn, Ulrich Müller, and Franz Viktor Spechtler. Walther von der Vogelweide: Epoche - Werk - Wirkung. 2nd ed. Arbeitsbücher zur Literaturgeschichte. Munich: C. H. Beck, 135-91.

Murray, Billie. (2021). Combating Hate: A Framework for Direct Action. Rhetoric and Democratic Deliberation Series. University Park: Penn State University Press, 2021.

Nelson-Campbell, Deborah, and Rouben Cholakian, ed. (2017). The Legacy of Courtly Literature: From Medieval to Contemporary Culture. Arthurian and Courtly Culture. Cham, Switzerland: Palgrave Macmillan.

Newhauser, Richard and Susan J. Ridyard, ed. (2012). Sin in Medieval and Early Modern Culture: The Tradition of the Seven Deadly Sins. Woodbridge: York Medieval Press.

Orefice, Paolo. (2020). Lo sviluppo delle discipline: Dall'indistinzione alla complessità [The Development of Disciplines: From Indisdinction to Complexity]. Florence, Italy: Firenze University Press.

Rafel, Burton, trans. (2009). The Song of the Cid: A Dual-Language Edition with Parallel Text. London: Penguin.

Rosenwein, Barbara H. and Riccardo Cristiani. (2018). What is the History of Emotions? What is History? series. Cambridge: Polity Press.

Rosenwein, Barbara H. ed. (1998). Anger's Past: The Social Uses of an Emotion in the Middle Ages. Ithaca and London: Cornell University Press, 1998.

Ruys, Juanita Feros, ed. (2008). What Nature Does Not Teach: Didactic Literature in the Medieval and Early-Modern Period. Disputatio, 15. Turnhout: Brepols.

Scholze, Ursula, ed. (2010). Das Nibelungenlied: Mittelhochdeutsch - Neuhochdeutsch [The Nibelungenlied: Middle High German - New High German]. Trans. and commentary by Siegfried Grosse. Stuttgart: Philipp Reclam jun.

Scott, Anne and Cynthia Kosso, ed. (2002). Fear and its Representations in the Middle Ages and Renaissance. Arizona Studies in the Middle Ages and Renaissance, vol. 6. Turnhout: Brepols.

Spiegel, Harriet, ed. and trans. (1994). Marie de France. Fables. Medieval Academy Reprints for Teaching. Toronto, Buffalo, and London: University of Toronto Press.

Stange, Manfred, ed., trans. (2016). Ulrich Bonerius. Der Edelstein: Eine mittelalterliche Fabelsammlung. Zweisprachige Ausgabe. Mittelhochdeutsch - Neuhochdeutsch [The Gemstone: A Medieval Collection of Fables: Bilingual Edition: Middle High German - New High German]. Uberstadt-Weiher, Heidelberg, et al.: verlag regionalkultur.

Stede, Marga. (1993). Schreiben in der Krise: Die Texte des Heinrich Kaufringer [Writing in a Time of Crisis: The Texts by Heirnich Kaufringer]. LIR Literatur, Imagination, Realität, 5. Trier: WVT Wissenschaftlicher Verlag. 
Sternberg, Robert J. and Karin Stenberg. (2008). The Nature of Hate. Cambridge and New York. Cambridge University Press.

Stiles, Anne, Stanley Finger, and François Boller, ed. (2013). Literature, Neurology, and Neuroscience: Historical and Literary Connections. Progress in Bain Research, 205. Amsterdam: Elsevier.

Tracy, Larissa, ed. (2019). Treason: Medieval and Early Modern Adultery, Betrayal, and Shame, ed. Larissa Tracy. Explorations in Medieval Culture, 10. Leiden and Boston: Brill.

Vermeule, Blakey. (2010). Why Do We Care About Literary Characters? Baltimore: Johns Hopkins University Press.

Volfing, Annette. (2010). “The Discourse of Bad Wives.” Regula Forster and Romy Günthart, ed. Didaktisches Erzählen: Formen literarischer Belehrung in Orient und Okzident [Didactic Narratives: Forms of Literary Instruction in the Orient and the Occident]. Frankfurt a. M., Berlin, et al.: Peter Lang, 277- 91.

Wenzel, Siegfried, ed. and trans. (1989). Fasciculus morum: A Fourteenth-Century Preacher's Handbook. University Park and London: The Pennsylvania State University Press.

Wolfram von Eschenbach. (2006). Parzival and Titurel, trans. with notes by Cyril Edwards. Oxford: Oxford University Press.

Zunshine, Lisa. (2006). Why We Read Fiction: Theory of Mind and the Novel. Columbus OH: Ohio State University Press. 